\title{
DIHYDROTESTOSTERONE DOWNREGULATES BONE RESORPTION ACTIVITY OF OSTEOCLASTS IN DOSE DEPENDENT MANNER: AN IN VITRO MODEL USING RAW 264.7 CELLS
}

\author{
HNIN EI THU ${ }^{1}$, ZAHID HUSSAIN ${ }^{2}$, ISA NAINA MOHAMED ${ }^{3}$, AHMAD NAZRUN SHUID ${ }^{* 4}$
}

${ }^{1}$ Department of Pharmacology, Faculty of Medicine, Universiti Kebangsaan Malaysia (The National University of Malaysia), Jalan Yaacob Latif 56000, Cheras, Malaysia, 2,3,4 Department of Pharmaceutics, Faculty of Pharmacy, Universiti Teknologi MARA, Puncak Alam Campus, Bandar Puncak Alam 42300, Selangor, Malaysia

Email: anazrun@yahoo.com

Received: 11 Jun 2017 Revised and Accepted: 31 Aug 2017

\section{ABSTRACT}

Objective: Numerous studies have evidenced the bone regulatory potential of dihydrotestosterone in androgen-deficient osteoporosis. The present study was thus aimed to explore the translational mechanism of dihydrotestosterone to down-regulate the bone resorption activity of osteoclasts using RAW 264.7 cells as in vitro model.

Methods: Prior to analyze the efficacy of dihydrotestosterone ( $5 \alpha$-DHT) to alleviate osteoclastic differentiation, their cell viability and cell proliferative ability was assessed using lactate dehydrogenase (LDH) and MTS assays. The osteoclastic differentiation capacity of dihydrotestosterone was evaluated by measuring TRAP activity and the expression of bone resorption-related proteins such as matrix metallopeptidase-9 (MMP-9), cathepsin-K, tartrate-resistant acid phosphatase (TRAP) and NFATc1. Moreover, the effects of dihydrotestosterone were also evaluated on superoxide (free radicals) generation and superoxide dismutase (SOD) activity in RANKL-induced osteoclasts.

Results: Dihydrotestosterone showed no toxicity towards RAW 264.7 cells and significantly enhanced their proliferation and growth rates in a dose-dependent fashion. It was also observed that dihydrotestosterone exhibits a remarkable inhibitory effect on differentiation, maturation and activation of osteoclasts. The marked inhibition of differentiation and activation of osteoclasts caused by $5 \alpha$-DHT was due to down-regulation of the expression of MMP-9, cathepsin-K, TRAP, NFATc1, generation of superoxide and up-regulation of SOD activity in the RAW 264.7 cells.

Conclusion: Resulting data provided substantially in vitro evidence for the pronounced anti-osteoclastogenetic activity of dihydrotestosterone and its therapeutic value in treating osteoporosis and other bone-erosive disorders.

Keywords: Androgen-deficient osteoporosis, Dihydrotestosterone, RAW 264.7 cells, Bone resorption, Anti-osteoclastogenesis

(C) 2017 The Authors. Published by Innovare Academic Sciences Pvt Ltd. This is an open-access article under the CC BY license (http://creativecommons.org/licenses/by/4.0/) DOI: http://dx.doi.org/10.22159/ijpps.2017v9i10.20651

\section{INTRODUCTION}

Bone metabolism is a physiologic process that maintains homeostasis between the bone resorption (the activity of osteoclasts) and formation (the activity of osteoblasts). Any deregulation in the homeostasis of this process may lead to bone diseases [1-3] including osteoporosis [4]. Osteoclasts are activated for many reasons, one of which is the imbalance of hormones caused by the menopause which may lead to various biochemical alternations in biochemical parameters of bone [5]. The absence of estrogen, induced by the menopause, increases the formation and the activity of osteoclasts which play key roles in bone loss and osteoclasts ultimately increase the risk of menopausal osteoporosis [6]. Therefore, inhibition of osteoclast formation, maturation and activation is an important therapeutic strategy.

Osteoclasts are multinucleated cells generated from monocyte/macrophage precursor cells, and osteoclast formation requires receptor activator of nuclear factor- $\kappa B(N F-\kappa B)$ ligand (RANKL). The receptor activator of NF- $\kappa B$ (RANK) is expressed on RAW 264.7 cell surfaces and conjugates with RANKL, which is essential for osteoclastogenesis [7]. RAW 264.7 cells have been well-recognized as osteoclast precursors. RAW 264.7 cells respond to RANKL stimulation in vitro to exhibit all characteristic features of fullydifferentiated matured osteoclast [8-10]. Upon activation, RAW 264.7 cells stimulate activation of an important transcription factor, nuclear factor of activated T-cells cytoplasmic 1 (NFATc1), for osteoclastogenesis [11]. As a master transcription factor of osteoclastogenesis, NFATc1 regulates diverse osteoclastogenesisrelated proteins such as TRAP, cathepsin-K and MMP-9 [12-14].

Numerous studies have evidenced the substantial roles of androgens (dihydrotestosterone) in the regulation of skeletal homeostasis in humans [15, 16] and rodents [17-20]. According to a recently published review [21], testosterone imparts promising roles in improving the bone health by enhancing the proliferation and differentiation of osteoblasts and down-regulating the maturation of osteoclasts. Despite of the numerous studies demonstrating the roles of dihydrotestosterone in regulating bone health $[22,23]$, the molecular and translational mechanism by which dihydrotestosterone regulates bone milieu and maintain homeostasis between bone formation and bone resorption is yet to be explored.

Thus, the present study was aimed to evident the potential effects of dihydrotestosterone on the proliferation, differentiation and maturation of osteoclasts in vitro. The cell proliferation activity of dihydrotestosterone was assessed using MTS assay. The cells differentiation ability was evaluated in terms of TRAP activity and the expression of specific osteoclast-related proteins including MMP-9, cathepsin-K, TRAP and NFATc1 in vitro. Moreover, the effects of dihydrotestosterone on the RANKL-induced generation of superoxide (free radicals) and SOD activity were also studied.

\section{MATERIALS AND METHODS}

\section{Materials}

RAW 264.7 cells were purchased from the American type culture collection (ATCC) cell bank (Manassas, VA, USA) and were used as in vitro model. Cell culture reagents Dulbecco modified eagles medium (DMEM), penicillin, streptomycin and foetal bovine serum (FBS) were sourced from Gibco laboratories (Grand Island, NY, USA). RANKL was purchased from Oriental Yeast Co., Ltd. (Tokyo, Japan). MTS (3-(4,5-dimethylthiazol-2-yl)-5-(3-carboxymethoxyphenyl)-2(4-sulfophenyl)-2 $\mathrm{H}$ tetrazolium) assay kit was purchased from Sigma-Aldrich, USA. Lactate dehydrogenase (LDH) cytotoxicity 
detection kit was purchased from Roche Diagnostics, Switzerland. $5 \alpha$-dihydrotestosterone ( $5 \alpha$-DHT) was purchased from Abcam, USA. ELISA kits for the expression of MMP-9, TRAP, cathepsin-K and NFATc1 were purchased from Elabscience Biotechnology Co., Ltd. (Wuhan, China). All other chemicals and reagents were sourced from pharmacology and cell culture laboratories of Faculty of Pharmacy, Universiti Teknologi MARA (UiTM), Malaysia.

\section{Treatment}

Prior to drug treatment, a stock solution $(1 \mathrm{ng} / \mathrm{ml})$ of $5 \alpha$-DHT was prepared using either DMEM or differentiation media. Different concentrations $(0.1,0.01$ and $0.001 \mathrm{ng} / \mathrm{ml})$ of $5 \alpha$-DHT were then prepared from the stock solution and were sterilized using $0.2 \mu \mathrm{m}$ syringe filter (Sartorius, Germany). RAW 264.7 cells were then treated with different concentrations of $5 \alpha$-DHT and culture media was replaced every other day throughout the experimental period.

\section{Cell culture and sub-culture}

RAW 264.7 cells were used as the osteoclast precursor cells. Cell culturing and sub-culturing were performed by growing active RAW 264.7 cells in a growth media consisting of DMEM supplemented with $10 \%$ heat-inactivated FCS and 1\% penicillin/streptomycin (Antibiotic/Antimycotic). Cells were then incubated in a humidified chamber $\left(95 \%\right.$ air and $\left.5 \% \mathrm{CO}_{2}\right)$ at $37{ }^{\circ} \mathrm{C}$ until they reached $80 \%$ confluence. The adhered cells were then released from the flask using cell scrapper and the removed cells were counted using a hemocytometer. For analyzing osteoclastic differentiation, cells were sparsely seeded at a density of $1 \times 10^{4}$ cells/well in 24 -well plate and were cultured under the same incubation circumstances. Cells were cultured for $24 \mathrm{~h}$ to obtain monolayers containing DMEM with $10 \%$ FCS to promote cell survival, division and metabolism. The cells were subsequently treated with or without $5 \alpha$-DHT at different concentrations $(0.1,0.01$ and $0.001 \mathrm{ng} / \mathrm{ml})$. These cultures were fed every other day by replacing the differentiation media with an identical volume of fresh media.

\section{Cytotoxicity assay}

LDH assay is a widely accepted measure of cellular toxicity. Changes in cellular health status are determined by use of indirect measures related to the formation of a colored tetrazolium dye product that can be measured spectrophotometrically at $490 \mathrm{~nm}$. An increase in the absorbance is indicative of an elevated release of cellular LDH, consequent to loss of cell membrane viability: a positive marker of toxicity (LDH assay).

Briefly, RAW 264.7 cells were seeded at a density of $1 \times 10^{4}$ cells/well in 24-well plate and cultured for $24 \mathrm{~h}$. After the cell adherence, culture media was changed and different doses of $5 \alpha$ DHT $(0.1,0.01$ and $0.001 \mathrm{ng} / \mathrm{ml})$ were added. Cells were cultured for additional $24 \mathrm{~h}$ and culture media was collected to test cytotoxicity.

LDH cytotoxicity assay was performed according to the manufacturer's protocol. This colourimetric assay quantifies the LDH released from the cytosol of damaged cells into the supernatant and thus serves as an index of cell death. Results were presented as optical density values (O. D) and percentage of cell viability of test groups relative to the control cells $(100 \%$ of cell viability) and of cells treated with $1 \%$ Triton $\mathrm{X}-100(0 \%$ cell viability) using the following equation.

$$
\text { Cell viability }(\%)=\frac{5 \alpha \text { DHT treated cells }- \text { control cells }}{\text { Triton treated cells }- \text { control cells }} \times 100
$$

\section{Cell proliferation assay}

Cell proliferation ability of $5 \alpha$-DHT was performed by using colorimetric [3-(4,5-dimethylthiazol-2-yl)-5-(3-carboxy-methoxyphenyl)-2-(4-sulfophenyl)-2H-tetrazolium] (MTS) assay. This colourimetric assay is based on the metabolic reduction of the MTS tetrazolium by the living cells to a formazan product. The absorbance of the formazan product was quantified at the wavelength of $490 \mathrm{~nm}$. Briefly, RAW 264.7 cells were seeded at a density of $1 \times 10^{4}$ cells/well in 24-well culture plates with six duplicate wells per treatment for cell proliferation assay and maintained in growth media for $24 \mathrm{~h}$ at $5 \% \mathrm{CO}_{2}$ at $37{ }^{\circ} \mathrm{C}$. After $24 \mathrm{~h}$ incubation, media was removed and the cells were treated with fresh growth media containing different concentrations $(0.1,0.01$ and $0.001 \mathrm{ng} / \mathrm{ml}$ ) of $5 \alpha-$ DHT and were cultured for additional $24 \mathrm{~h}$. Normal growth medium (without $5 \alpha$-DHT) was used as untreated (normal control). After $24 \mathrm{~h}$ of incubation, $20 \mu \mathrm{l}$ of diluted MTS solution was added to each well and cells were further incubated at $37{ }^{\circ} \mathrm{C}$ in the dark after being covered with aluminium foil for additional $2 \mathrm{~h}$. The absorbance of each well was recorded using microplate reader.

\section{Cell differentiation and tested groups}

RAW 264.7 cells differentiate into mature osteoclasts after stimulating with RANKL. For that, RAW 264.7 cells were cultured in DMEM with $10 \%$ FBS and $1 \%$ penicillin/streptomycin and seeded in 24 wells culture plates at a density of $1 \times 10^{4}$ cells/well and placed in the $\mathrm{CO}_{2}$ incubator overnight to allow the cells to adhere to the well surfaces. After $24 \mathrm{~h}$, the culture media was replaced with osteoclastic differentiation media and five groups were made: (1) first group was untreated (normal control) containing RAW 264.7 cells cultured with normal growth media, (2) Second group was RANKL-treated cells (RANKL induced control) in which RAW 264.7 cells were incubated with differentiation media containing $50 \mathrm{ng} / \mathrm{ml}$ RANKL, (3) third group was RANKL-induced RAW 264.7 cells that were treated with $0.1 \mathrm{ng} / \mathrm{ml}$ of $5 \alpha$-DHT, (4) fourth group was RANKL-induced RAW 264.7 cells that were treated with $0.01 \mathrm{ng} / \mathrm{ml}$ of $5 \alpha$-DHT, (5) fifth group was RANKL-induced RAW 264.7 cells that were treated with $0.001 \mathrm{ng} / \mathrm{ml}$ of $5 \alpha$-DHT.

\section{TRAP activity}

To analyze the extent of osteoclastic differentiation, RAW 264.7 cells were cultured in 24-well cell culture plates at a density of $1 \times 10^{4}$ cells/well and induced with differentiation medium after being treated with $5 \alpha$-DHT at different concentrations $(0.1,0.01$ and 0.001 $\mathrm{ng} / \mathrm{ml}$ ) or left untreated (normal control) for $5 \mathrm{~d}$. The medium was changed every other day. Afterward, the medium was removed and the cell monolayer was gently washed twice using ice-cold PBS. The cells were fixed in $3.5 \%$ formaldehyde for $10 \mathrm{~min}$ and ethanol/acetone (1:1) for $1 \mathrm{~min}$. Subsequently, the dried cells were incubated in a 50-mM citrate buffer $(\mathrm{pH} 4.5)$ containing $10 \mathrm{mmol}$ sodium tartrate and $6 \mathrm{mmol}$ of $p$-nitrophenyl phosphate (PNPP). After $1 \mathrm{~h}$ of incubation, the reaction mixtures were transferred to new well plates containing an equal volume of $0.1 \mathrm{~N} \mathrm{NaOH}$. Absorbance was measured at $405 \mathrm{~nm}$ using an enzyme-linked immunoassay reader and TRAP activity was expressed as optical density compared to the controls.

\section{Expression of protein markers}

In this experiment, the potential biological influence of $5 \alpha$-DHT on the expression and regulation of specific RANKL-induced osteoclastfunctional protein biomarkers such as MMP-9, TRAP, cathepsin-K and NFATc1 was investigated. These proteins are major phenotypic markers for osteoclast differentiation during bone resorption.

The expression of the above bone-resorption protein markers was measured using sandwich ELISA method. In this technique, the culture plates were pre-coated with antibodies specific to the protein marker. These pre-coated antibodies specifically bind to their protein markers in the sample. The biotinylated detection antibody specific for each protein markers were added to sandwich the bound protein markers and were detected as changes in color. The optical density (OD) values were recorded at $450 \mathrm{~nm}$ and the intensity of the color is directly proportional to expression concentration of each protein marker in the sample. The sensitivity of detection for MMP-9, TRAP, cathepsin-K and NFATc1 were 18.75, $78.5,10$, and $1.0 \mathrm{pg} / \mathrm{ml}$, respectively.

\section{Superoxide production}

Superoxide concentration was measured using a green chemiluminescence CD kit according to the manufacturer's instructions. The green chemiluminescent $C D$ is a highly sensitive chemiluminescence probe that reacts with the superoxide anion and a luminescence dye specific for the detection of superoxide. Briefly, RAW 264.7 cells were cultured in 24-well cell culture plates at a 
density of $1 \times 10^{4}$ cells/well and were left untreated or treated with different concentrations of $5 \alpha$-DHT $(0.1,0.01$ and $0.001 \mathrm{ng} / \mathrm{ml})$. The contents of the kit were dissolved in hot methanol: water $(1: 1 \mathrm{v} / \mathrm{v})$ containing $0.1 \%(\mathrm{w} / \mathrm{v})$ trifluoroacetic acid. To measure superoxide generated into the media, $200 \mu \mathrm{l}$ of the media was mixed with $150 \mu \mathrm{l}$ of the reagent. The luminescence intensity of each sample was measured using a luminescence plate reader. The value for each treated group was converted to a percentage of the control luminescence.

\section{SOD activity}

SOD activity expressed in each cell culture media was measured using an SOD assay kit-WST according to the manufacturer's instructions (Dojindo Molecular Technologies, Inc., Kumamoto, Japan). Briefly, RAW cells were seeded in a 24 -well plate at a density of $1 \times 10^{4}$ cells/well and were left untreated or treated with different concentrations of $5 \alpha$-DHT $(0.1,0.01$ and $0.001 \mathrm{ng} / \mathrm{ml})$. The SOD activity was measured by mixing the reagents from $220 \mu \mathrm{l}$ of the WST kit with $20 \mu \mathrm{l}$ of the culture medium. After $20 \mathrm{~min}$ incubation at $37^{\circ} \mathrm{C}$, absorbance was measured at $450 \mathrm{~nm}$ using a microplate reader (Bio-Rad Model 680; Bio-Rad, Hercules, CA, USA). The value for each treated group was converted to a percentage of the value obtained for the control group.

\section{Statistical analysis}

Data were analyzed using one-way analysis of variance (one-way ANOVA) followed by Student's t-test using SPSS version 21.0. All the experiments were performed independently three times with quadruplicate sampling $(n=12)$. Data were presented as mean \pm standard deviation (SD). A significant difference was recognized by ${ }^{\# \#} \mathrm{P}<0.01$ represent a significant difference between normal control and RANKL induced control group and ${ }^{* *} \mathrm{P}<0.01$ and ${ }^{*} \mathrm{P}<0.05$ represents significant differences between treated $(5 \alpha-$ DHT) and RANKL induced control groups.

\section{RESULTS}

Effect of $5 \alpha$-DHT on cell viability and cytotoxicity of RAW 264.7 cells

The cytotoxicity of $5 \alpha$-DHT on RAW 264.7 cells was investigated by measuring cell viability using LDH assay. RAW 264.7 cells were incubated with different concentrations of $5 \alpha$-DHT and their cell viability was measured on days 1 and 5 compared to the control groups (normal control and RANKL induced control) (table 1). Results demonstrated no cytotoxicity of $5 \alpha$-DHT at different concentrations $(0.1,0.01$ and $0.001 \mathrm{ng} / \mathrm{ml})$ in RAW 264.7 cells with or without RANKL-induction on days 1 and 5 (table 1 ). The viability of cells at all the tested concentrations was $>100 \%$.

Table 1: Effect of 5 $\alpha$-DHT on RAW 264.7 cells viability. RAW cells were treated with different concentrations of $5 \alpha$-DHT (0.1, 0.01 , and $0.001 \mathrm{ng} / \mathrm{ml}$ ) for different time durations (days 1 and 5) with or without stimulating by RANKL. Data are representative of results from three independent experiments in quadruplicate sampling $(n=12)$. Data are expressed as percentages of the value of the control cells (mean \pm Standard deviation)

\begin{tabular}{|c|c|c|c|c|c|c|c|c|c|c|c|}
\hline \multirow{2}{*}{$\begin{array}{l}\begin{array}{l}\text { Test } \\
\text { groups }\end{array} \\
\text { Time } \\
\text { duratio } \\
\text { n }\end{array}$} & \multicolumn{2}{|c|}{ Normal control } & \multicolumn{3}{|c|}{ DHT-0.1 (0.1 ng/ml) } & \multicolumn{3}{|c|}{ DHT-0.01 (0.01 ng/ml) } & \multicolumn{3}{|c|}{ DHT-0.001 (0.001 ng/ml) } \\
\hline & Day-1 & Day-5 & Day-1 & $\begin{array}{l}\text { Day-5 } \\
(- \\
\text { RANKL) }\end{array}$ & $\begin{array}{l}\text { Day-5 } \\
\text { (+RANKL } \\
\text { ) }\end{array}$ & Day-1 & $\begin{array}{l}\text { Day-5 } \\
(- \\
\text { RANKL })\end{array}$ & $\begin{array}{l}\text { Day-5 } \\
\text { (+RANKL } \\
\text { ) }\end{array}$ & Day-1 & $\begin{array}{l}\text { Day-5 } \\
(- \\
\text { RANKL) }\end{array}$ & $\begin{array}{l}\text { Day-5 } \\
\text { (+RANKL } \\
\text { ) }\end{array}$ \\
\hline O. D & $0.23 \pm 0.0$ & $0.28 \pm 0.0$ & $0.25 \pm 0.0$ & $0.34 \pm 0.0$ & $0.32 \pm 0.0$ & $0.24 \pm 0.0$ & $0.30 \pm 0.0$ & $0.31 \pm 0.0$ & $0.24 \pm 0.0$ & $0.31 \pm 0.0$ & $0.30 \pm 0.0$ \\
\hline $\begin{array}{l}\text { values } \\
(490 \\
\mathrm{nm})\end{array}$ & 5 & 3 & 2 & 5 & 3 & 2 & 6 & 3 & 5 & 7 & 6 \\
\hline $\begin{array}{l}\% \text { cell } \\
\text { viability }\end{array}$ & $100 \pm 6$ & $100 \pm 7$ & $105 \pm 9$ & $112 \pm 5$ & $106 \pm 6$ & $102 \pm 8$ & $104 \pm 4$ & $105 \pm 8$ & $101 \pm 7$ & $105 \pm 6$ & $104 \pm 4$ \\
\hline
\end{tabular}

\section{Effect of $5 \alpha$-DHT on proliferation of RAW 264.7 cells}

To evaluate the effect of different doses of $5 \alpha$-DHT on the growth rate of RAW 264.7 cells, cell proliferation assay was performed. Briefly, RAW 264.7 cells were subjected different concentrations of $5 \alpha$-DHT $(0.1,0.01$ and $0.001 \mathrm{ng} / \mathrm{ml}$ ) and their cell growth rate was measured using MTS assay and results were compared to the control group (table 2). A significant increase in cell growth was observed in RAW 264.7 cells treated with different concentrations of $5 \alpha$-DHT particularly 0.1 and 0.01 $\mathrm{ng} / \mathrm{ml}$, on day-1 (table 2) compared to the untreated (normal control) group. The cell growth was further increased when the duration of incubation was increased (day-5). The increase in cell growth was dosedependent and the highest cell growth was observed in RAW 264.7 cells treated with $0.1 \mathrm{ng} / \mathrm{ml}$ concentration. These results indicated that $5 \alpha$ DHT is safe and significantly $\left({ }^{*} \mathrm{P}<0.05\right)$ enhance cells proliferation in RAW 264.7 cells (table 2).

Table 2: Effect of $5 \alpha$-DHT on RAW 264.7 cells proliferation. RAW cells were treated with different concentrations of $5 \alpha$-DHT (0.1, 0.01, and $0.001 \mathrm{ng} / \mathrm{ml}$ ) for different time durations (days 1 and 5) with or without stimulating by RANKL. Data are representative of results from three independent experiments in quadruplicate sampling $(n=12)$. Data are expressed as percentages of the value of the control cells (mean \pm standard deviation)

\begin{tabular}{|c|c|c|c|c|c|c|c|c|c|c|c|}
\hline \multirow{2}{*}{$\begin{array}{l}\text { Test groups } \\
\text { Time } \\
\text { duration }\end{array}$} & \multicolumn{2}{|c|}{ Normal control } & \multicolumn{3}{|c|}{ DHT-0.1 (0.1 ng/ml) } & \multicolumn{3}{|c|}{ DHT-0.01 (0.01 ng/ml) } & \multicolumn{3}{|c|}{ DHT-0.001 (0.001 ng/ml) } \\
\hline & Day-1 & Day-5 & Day-1 & $\begin{array}{l}\text { Day-5 } \\
(- \\
\text { RANKL) }\end{array}$ & $\begin{array}{l}\text { Day-5 } \\
\text { (+RANKL } \\
\text { ) }\end{array}$ & Day-1 & $\begin{array}{l}\text { Day-5 } \\
(- \\
\text { RANKL) }\end{array}$ & $\begin{array}{l}\text { Day-5 } \\
\text { (+RANKL } \\
\text { ) }\end{array}$ & Day-1 & $\begin{array}{l}\text { Day-5 } \\
(- \\
\text { RANKL) }\end{array}$ & $\begin{array}{l}\text { Day-5 } \\
\text { (+RANKL } \\
\text { ) }\end{array}$ \\
\hline O. D values & $0.27 \pm 0$ & $0.34 \pm 0.0$ & $0.36 \pm 0.1$ & $0.48 \pm 0.1$ & $0.46 \pm 0.1$ & $0.34 \pm 0.0$ & $0.44 \pm 0.0$ & $0.43 \pm 0.1$ & $0.31 \pm 0.0$ & $0.41 \pm 0.0$ & $0.39 \pm 0.0$ \\
\hline$(490 \mathrm{~nm})$ & 08 & 6 & 1 & 5 & 3 & 7 & 9 & 2 & 9 & 7 & 9 \\
\hline $\begin{array}{l}\% \text { cell } \\
\text { proliferation }\end{array}$ & $100 \pm 8$ & $100 \pm 6$ & $110 \pm 5$ & $121 \pm 9$ & $119 \pm 6$ & $108 \pm 3$ & $117 \pm 6$ & $115 \pm 7$ & $105 \pm 6$ & $112 \pm 8$ & $110 \pm 5$ \\
\hline
\end{tabular}

Effect of $5 \alpha$-DHT on RANKL-induced differentiation of RAW 264.7 cells

RAW 264.7 cells were exposed to RANKL (50 ng/ml) to fully differentiate them into the mature multinucleated TRAP-positive cells to further examine the effect of $5 \alpha$-DHT on osteoclastogenesis.
The RANKL-induced differentiation potential of RAW 264.7 cells was evaluated by measuring TRAP activity of different cell cultures treated with different concentrations of $5 \alpha$-DHT compared to the control groups (normal and RANKL induced controls) (fig. 1). Results showed that TRAP activity was negligibly low in all the tested groups on day-1; 
however, it was enormously high at day-5. At day-5, a significantly $(\# \#<0.05)$ higher TRAP activity was observed in the RANKL-induced control group compared to the normal control group (fig. 1). However, in RAW 264.7 cells treated with $5 \alpha$-DHT, a dose-dependent significant decrease in TRAP activity was observed compared to the RANKL induced control group. Comparative analysis revealed that the decrease of TRAP activity was more obvious in RAW 264.7 cells treated with $0.1 \mathrm{ng} / \mathrm{ml}\left({ }^{* *} \mathrm{P}<0.05\right)$ (fig. 1$)$.

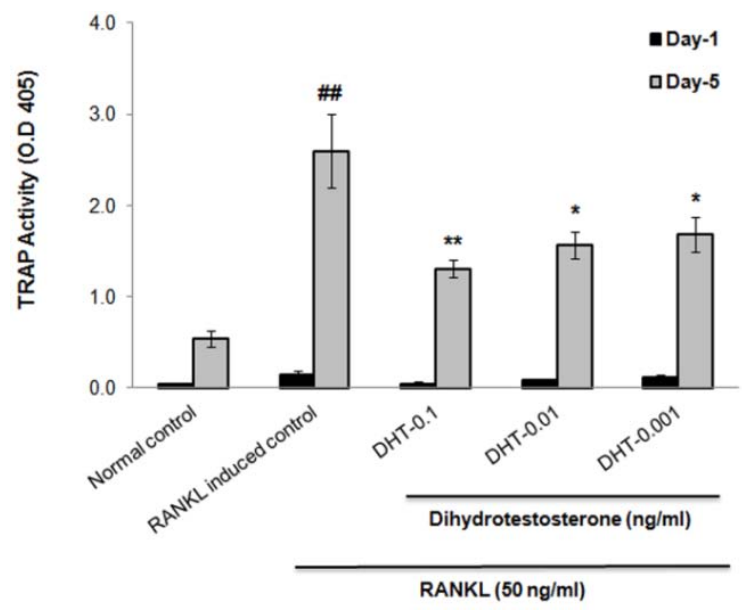

Fig. 1: Effect of $5 \alpha$-DHT on tartrate-resistant acid phosphatase (TRAP) activity in RANKL-induced RAW 264.7 cells. TRAP activity was measured using ELISA reader (optical density, 405 $\mathrm{nm}$ ). Data are represented as the means \pm standard deviation of three independent experiments in quadruplicate sampling

$(\mathrm{n}=12)$. ${ }^{\# \# P<0.01}$ compared with normal; ${ }^{* *} \mathrm{P}<0.01$ and ${ }^{*} \mathrm{P}<0.05$ compared with RANKL induced control group

\section{Effect of $\mathbf{5} \alpha$-DHT on protein biomarkers}

To evaluate the effect $5 \alpha$-DHT on the bone resorption capacity of osteoclasts, we measured the expression of various phenotypic bone resorption-related proteins including MMP-9, cathepsin K, TRAP and NFATc1 in RAW 264.7 cell cultures treated with $5 \alpha$-DHT.

\section{Expression of MMP-9}

To examine the effect of $5 \alpha$-DHT on the expression of MMP-9, a sandwich ELISA test was performed and the results were compared with an untreated (normal control) group (fig. 2A). Resulting data demonstrated that the expression of MMP-9 was negligibly low at day-1; however, an enormous increase in its expression was observed on day-5 in all the experimental groups (fig. 2A). Comparative analysis revealed that the expression of MMP-9 was significantly $(\# \# \mathrm{P}<0.01)$ high in RANKL induced control group compared to the normal control on day-5. A significant dosedependent decrease in the expression of MMP-9 was observed in $5 \alpha$ DHT treated RAW 264.7 cells at different concentrations compared to RANKL induced control group. The decrease in the expression of MMP-9 was more pronounced in RAW 264.7 cells treated with 0.1 $\mathrm{ng} / \mathrm{ml}\left({ }^{* *} \mathrm{P}<0.01\right)$ (fig. $\left.2 \mathrm{~A}\right)$

\section{Expression of cathepsin- $\mathrm{K}$}

To evaluate the effect of $5 \alpha$-DHT on the expression patterns of cathepsin-K in RANKL-induced RAW 264.7 cells was estimated using sandwich ELISA technique and the results were compared with normal control group (fig. 2B). Results showed that the expression of cathepsin-K was enormously high at day- 5 compared to day- 1 in all the experimental groups. A significantly highest expression of cathepsin-K was observed in RANKL induced control group on day-5 compared to the other tested groups $(\# \# P<0.01)$. However, the treatment of RANKL induced RAW 264.7 cells with $5 \alpha$-DHT showed a dose-dependent decrease in the levels of cathepsin-K. The decrease was more obvious at $0.1 \mathrm{ng} / \mathrm{ml}\left({ }^{* *} \mathrm{P}<0.01\right)$ compared to other treated and untreated groups (fig. 2B).
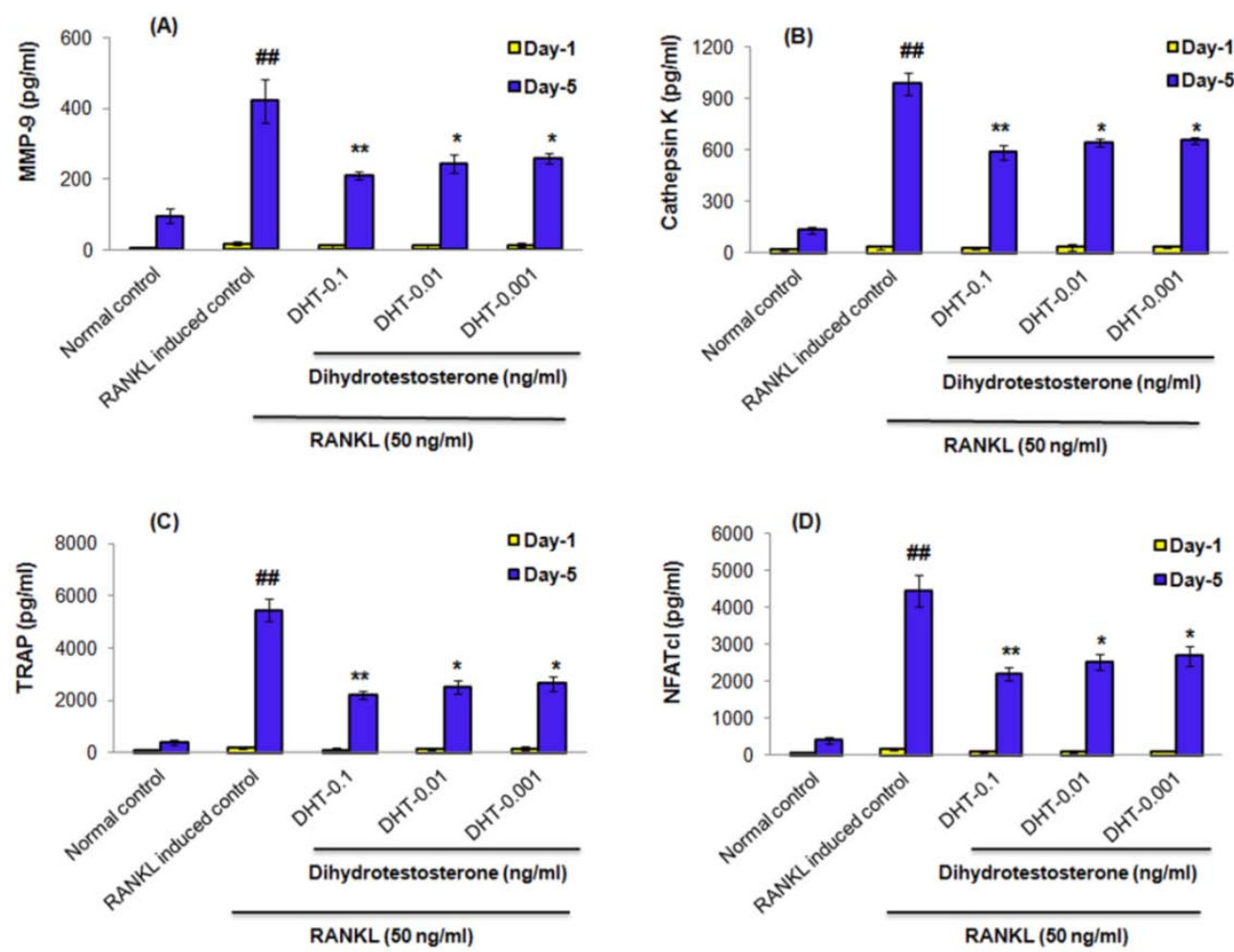

Fig. 2: Effect of $5 \alpha$-dihydrotestosterone ( $5 \alpha$-DHT) on the expression of matrix mettaloproteinase-9 (MMP-9) (A), Cathepsin-K (B), tartrateresistant acid phosphatase (TRAP) activity (C), and NFATc1 (D) in RANKL-stimulated RAW 264.7 cells using sandwich ELISA. Data are represented as the means \pm standard deviation of three independent experiments in quadruplicate sampling $(n=12)$. \#\# $P<0.01$ represent significant difference between RANKL induced control and normal control groups; ${ }^{* *} \mathbf{P}<0.01$ and ${ }^{*} \mathbf{P}<0.01$ represent significant difference between $5 \alpha$-DHT-treated and RANKL-induced groups 


\section{Expression of TRAP}

In this experiment, the effect of $5 \alpha$-DHT on the sequential expression of TRAP was evaluated in RANKL induced RAW 264.7 cells and the results were compared with RANKL induced control and normal control groups (fig. 2C). Results demonstrated that the expression of TRAP was lowest on day-1 in all the experimental groups; however, an enormous increase in the expression of TRAP was observed on day-5. Results showed that the expression intensity of TRAP in RANKL induced control group was significantly high $(\# \# P<0.01)$ compared to the normal control group at day-5. The resulting pattern demonstrated a systematic physiological correlation between the expression of TRAP and osteoclastogenesis. Notably, results showed a significant dose-dependent decrease in the expressional intensity of TRAP in $5 \alpha$-DHT treated RAW 264.7 cells compared to the RANKL induced control group. Further analysis revealed that highest decrease in the TRAP expression was observed at $0.1 \mathrm{ng} / \mathrm{ml}\left({ }^{* *} \mathrm{P}<0.01\right)$ compared to the other tested groups (fig. $\left.2 \mathrm{C}\right)$.

\section{Expression of NFATc1}

To examine the effect of $5 \alpha$-DHT on osteoclastogenesis and bone resorption, we have also measured the expression of one NFATc1. NFATc1 is known to be a master transcription factor in osteoclastogenesis [24-26]. The effect of different concentrations of $5 \alpha$-DHT on the expression of NFATc1 was evaluated using sandwich ELISA (fig. 2D). The resulting data showed that the expression of NFATc1 was significantly ( ${ }^{\# P} \mathrm{P}<0.01$ ) high in RANKL induced control group compared to the normal control group at day-5. At day-1, negligibly lower expressions of NFATc1 were observed in all the experimental groups. Results also showed that a significant dosedependent decrease in the expression intensity of NFATc1 was observed in $5 \alpha$-DHT treated RAW 264.7 cell cultures compared to the RANKL induced control group and the highest decrease was observed in RAW 264.7 cells treated with $0.1 \mathrm{ng} / \mathrm{ml}\left({ }^{* *} \mathrm{P}<0.01\right)$ (fig. 2D).

\section{Effect of $5 \alpha$-DHT on superoxide production and SOD activity}

This experiment was performed to evaluate the effect of $5 \alpha$-DHT on the reactive oxygen species (ROS) and superoxide production in RANKL-induced RAW 264.7 cells and the results were compared with normal and RANKL induced control groups (fig. 3A). The resulting data depicted that the production of superoxide was significantly high in RANKL induced group (taken as 100\%) on day5. However, a dose-dependent decrease in superoxide production was observed in $5 \alpha$-DHT treated RAW 264.7 cells compared to the RANKL induced control group. Comparative analysis revealed that the inhibition of superoxide production was more obvious at 0.1 $\mathrm{ng} / \mathrm{ml}$ of $5 \alpha$-DHT compared to other treatment groups.

On the other hand, we have also examined the effect of $5 \alpha$-DHT on SOD activity in RANKL-induced RAW 264.7 cells and the results were compared with normal control group (fig. 3B). Resulting data showed that higher SOD levels were observed in $5 \alpha$-DHT treated RAW 264.7 cells compared to the RANKL induced control and normal control groups. The comparative analysis revealed that the highest SOD activity was observed in RAW 264.7 cells treated with $0.1 \mathrm{ng} / \mathrm{ml}\left({ }^{* *} \mathrm{P}<0.01\right)$ compared to other treatment groups. Further analysis revealed that SOD levels were increased in a dosedependent manner in $5 \alpha$-DHT treated groups (fig. 3B).
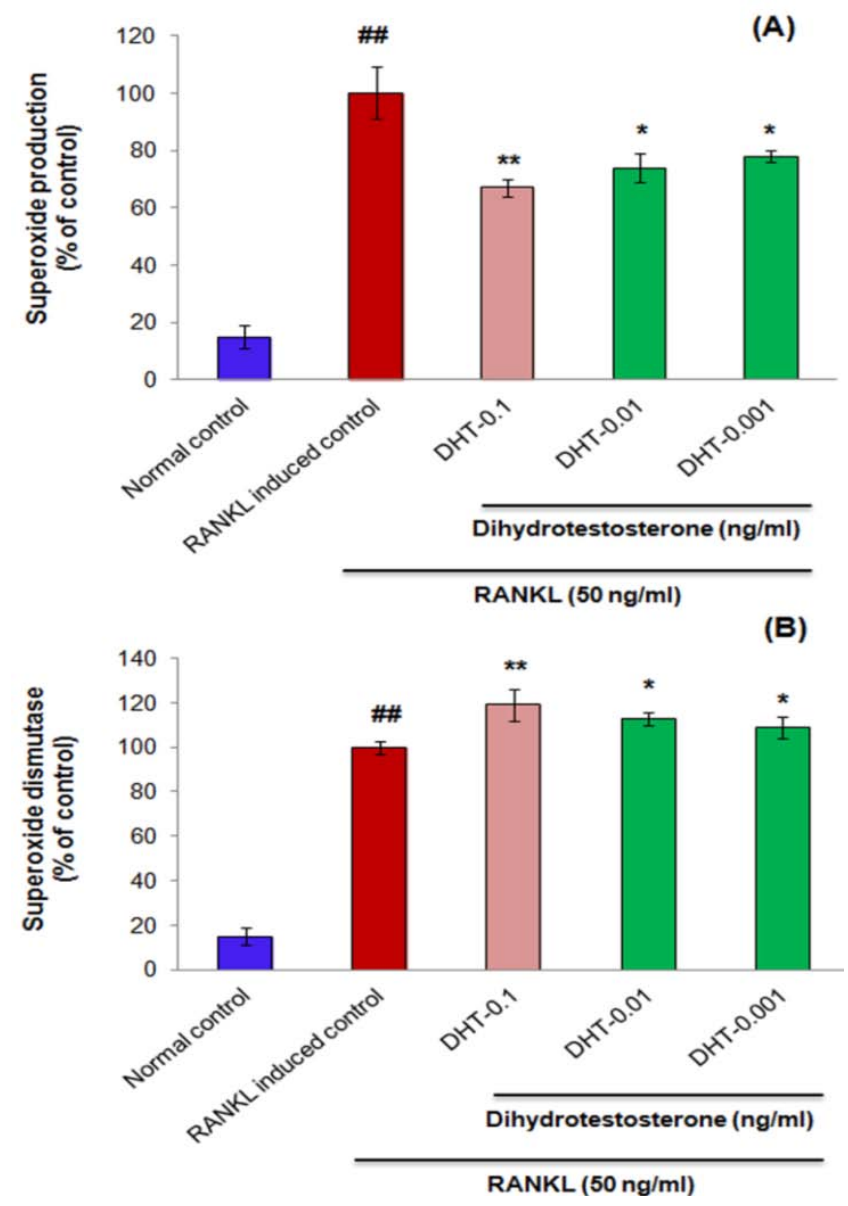

Fig. 3: Effect of $5 \alpha$-dihydrotestosterone ( $5 \alpha$-DHT) on superoxide production (A) and superoxide dismutase (SOD) activity (B). RAW 264.7 cells were stimulated with RANKL and treated with different concentrations $(0.1,0.01$, and $0.001 \mathrm{ng} / \mathrm{ml})$ of $5 \alpha$-DHT for $5 \mathrm{~d}$. Superoxide production was measured by luminescence intensity assay. SOD activity was measured at $450 \mathrm{~nm}$ using a microplate reader. Data are representative of results from three independent experiments in quadruplicate sampling $(n=12)$. Data are expressed as percentages of the value of the control cells (mean $\pm S$. $D, n=12$ ). ${ }^{*} P<0.05$ and ${ }^{* *} \mathrm{P}<0.01$ represent significant difference between tested and $R A N K L$ induced control group and ${ }^{\# \#} \mathrm{P}<0.01$ represent significant difference between RANKL induced control and normal control, groups 


\section{DISCUSSION}

Osteoporosis is a metabolic disease in which skeletal integrity is compromised due to decreased bone mass, leading to a significantly enhanced risk of skeletal fracture. Among the major pharmacological interventions used for the management of osteoporosis, estrogen replacement therapy, bisphosphonates [27], selective estrogen receptor modulators, and calcitonin are most commonly employed. However, these therapies are also associated with several adverse effects including breast cancer, hypercalcemia and hypertension. Numerous in vitro, in vivo and human clinical studies have evidenced the substantial anti-osteoporotic efficacy of $5 \alpha$-DHT and their roles in the regulation of skeletal homeostasis [15-20]. Chen et al. [17] demonstrated that $5 \alpha$-DHT inhibits osteoclast formation, differentiation and maturation by blocking androgen receptors. The involvement and prime importance of androgen receptors and estrogen receptors has also been critically discussed by Mohamed et al. [21]. They demonstrated that $5 \alpha$-DHT regulates bone health via blocking androgen and estrogen receptors.

TRAPs are expressed particularly in osteoclasts and are commonly used as phenotype markers of osteoclasts; treatment of RAW 264.7 cells with RANKL has been shown to easily induce cell differentiation into osteoclasts, which are TRAP-positive cells [28]. The study of TRAPpositive cell formation and activity is a well-known method of determining osteoclast formation and function [29]. In this study, we evidenced that $5 \alpha$-DHT significantly inhibited TRAP activity which indicates its promising inhibitory potential on osteoclastogenesis.

Moreover, we evaluated the effect of $5 \alpha$-DHT on the regulation and expression of various key osteoclastogenesis-related protein biomarkers such as MMP-9, cathepsin-K, TRAP and NFATc1 in RANKL-induced RAW 264.7 cells. The resulting data revealed that $5 \alpha$-DHT significantly downregulates the expression of all the protein markers responsible for osteoclastic activity and their maturation.

MMP-9 plays a critical role in the initiation of the osteoclastmediated bone resorption process by removing the collagenous layer from the bone surface prior to demineralization [30]. Furthermore, MMP-9 is one of the most important phenotypic biomarkers to anticipate the bone resorption mechanism [31]. In this study, the resulting data revealed that the treatment of RAW 264.7 cells with $5 \alpha$-DHT results in a dose-dependent decrease in the expression of MMP-9 which indicates that $5 \alpha$-DHT exhibit promising potential to downregulate bone resorption. For digestion and solubilization of the bone matrix, the ruffled border secretes enzymes and protons after attachment to the bone. Cathepsin- $\mathrm{K}$ activity is required to start actin ring formation and, thus, activation and functioning of osteoclasts [32]. Our results clearly demonstrated that the treatment of RAW 264.7 cells with $5 \alpha$-DHT resulted in a dose-dependent decrease in the expression of cathepsin-K in vitro.

Several studies have demonstrated that NFATc1 is an important transcription factor for RANKL-mediated osteoclast differentiation, fusion and activation [33,34]. It has also been noted that over-expression of NFATc1 induces differentiation into osteoclasts even in cases of RANKL deficiency [35]. Moreover, in NFATc1 knock-out mice, defective osteoclast differentiation and osteopetrosis have been noted. NFATc1 plays an important role in osteoclast activation through the release of osteoclastogenesis-related genes such as TRAP and MMP-9 and the expression of these mediators is mainly responsible for the degradation of bone mineral and collagen matrices [12-14]. In the present study, we noticed that $5 \alpha$-DHT exerted significant inhibitory effects on the expression of NFATc1 in vitro.

ROS have been recognized as secondary messengers and play pivotal roles in regulating the differentiation of osteoclasts. Excessive ROS production results in an abnormal osteoclastogenesis and results in overproduction of osteoclasts [36]. By contrast, excessive ROS production results in an over-activation of osteoclast functions due to an increase in the number of osteoclasts [37]. Additionally, ROS production by osteoporotic bone tissue is significantly higher compared to normal bone tissue [38]. Several studies have reported that the ROS level increases during RANKL-induced osteoclast differentiation. Thus, to investigate whether $5 \alpha$-DHT can inhibit superoxide generation during osteoclast differentiation, the production of superoxide was analyzed. Our resulting data evidenced that the treatment of RANKL-induced osteoclast with $5 \alpha$ DHT significantly inhibited the production of ROS in a dosedependent manner.

SOD is an importantantioxidant defence in nearly all living cells including osteoclasts cells. This an enzyme alternately catalyzes the dismutation of the superoxide (02-) radicals into either ordinary molecular oxygen (02) or hydrogen peroxide (H2O2) and thus play an important role in maintaining and regulating homeostasis in bodily tissues including bone matrices. Hence, despite of the significant downregulation of ROS production, we have also evaluated its effect on SOD levels. Our results indicated that $5 \alpha$-DHT showed significant upregulation in SOD activity, suggesting that $5 \alpha$-DHT has a positive effect on increasing antioxidant defence in RANKL induced RAW 264.7 cells.

\section{CONCLUSION}

In this study, the effect of dihydrotestosteron was systematically observed on the proliferation, differentiation, maturation, and activation of osteoclasts (RAW 264.7 cells). Our results evidenced that treatment of RAW 264.7 cells with $5 \alpha$-DHT exhibits remarkable inhibitory effects on the bone resorption ability of osteoclasts. The inhibitory effects $5 \alpha$-DHT on the differentiation and functioning of osteoclasts are regulated through mechanisms involving down-regulation of RANKL-induced TRAP activity and expression of various bone-resorption related protein biomarkers including MMP-9, cathepsin-K, TRAP and NFATc1. Taken together, suppression of superoxide generation and enhanced SOD activity also mediates pivotal role in alleviating the over-activation and functioning of osteoclasts. Our findings suggest that $5 \alpha$-DHT exhibit promising potential for the treatment of bone diseases associated with excessive bone resorption.

\section{ACKNOWLEDGEMENT}

Authors would like to acknowledge Universiti Teknologi MARA for providing LESTARI grant (600-IRMI/DANA 5/3/IESTARI $(0007 / 2016))$ and support to compete for the present research project. Authors would also like to acknowledge Ministry of Agriculture for providing New Application for Herbal Research Grant Scheme (NRGS) (NH1014D040).

\section{AUTHOR CONTRIBUTION}

The experiments were conceived and designed by Ahmad Nazrun Shuid (ANS). The experiments were performed and executed by Hnin Ei Thu (HET). Manuscript was written by HET and ANS. Data were analysed by ANS, HET, Isa Naina Mohamed (INM) and Zahid Hussain $(\mathrm{ZH})$. The reagents, materials and analytical tools were contributed by HET, ANS, INM and ZH.

\section{CONFLICT OF INTERESTS}

The authors declare that they have no competing interests

\section{REFERENCES}

1. Teitelbaum SL. Bone resorption by osteoclasts. Science 2000;289:1504-8.

2. Rodan GA, Martin TJ. Therapeutic approaches to bone diseases. Science 2000;289:1508-14.

3. Boyle WJ, Simonet WS, Lacey DL. Osteoclast differentiation and activation. Nature 2003;423:337-42.

4. Burge R, Dawson-Hughes B, Solomon DH, Wong JB, King A, Tosteson A. Incidence and economic burden of osteoporosisrelated fractures in the United States, 2005-2025. J Bone Miner Res 2007;22:465-75.

5. Preeti Sharma. Biochemical alterations in postmenopausal women having an osteoporic risk. Asian J Pharm Clin Res 2017;10:214-7.

6. Pradeep Kumar. Assessment of uric acid in post-menopausal osteoporotic women. Asian J Pharm Clin Res 2016;9:138-9.

7. Suda T, Takahashi N, Udagawa N, Jimi E, Gillespie MT, Martin TJ. Modulation of osteoclast differentiation and function by the new members of the tumor necrosis factor receptor and ligand families. Endocr Rev 1999;20:345-57.

8. Mizukami J, Takaesu G, Akatsuka H, Sakurai H, Ninomiya-Tsuji J, Matsumoto K, et al. Receptor activator of NF-kappa B ligand 
(RANKL) activates TAK1 mitogen-activated protein kinase kinase kinase through a signaling complex containing RANK, TAB2, and TRAF6. Mol Cell Biol 2002;22:992-1000.

9. Wittrant Y, Theoleyre S, Couillaud S, Dunstan C, Heymann D, Rédini F. Relevance of an in vitro osteoclastogenesis system to study receptor activator of NF-kB ligand and osteoprotegerin biological activities. Exp Cell Res 2004;293:292-301.

10. Komarova SV, Pereverzev A, Shum JW, Sims SM, Dixon SJ. Convergent signaling by acidosis and receptor activator of NFkappa B ligand (RANKL) on the calcium/calcineurin/NFAT pathway in osteoclasts. Proc Natl Acad Sci USA 2005;102:2643-8.

11. Grigoriadis AE, Wang ZQ Cecchini MG, Hofstetter W, Felix R, Fleisch HA, et al. c-Fos: a key regulator of osteoclast-macrophage lineage determination and bone remodeling. Science 1994;266:443-8.

12. Zhao $Q$, Wang $X$, Liu $Y$, He A, Jia R. NFATc1: functions in osteoclasts. Int J Biochem Cell Biol 2010;42:576-9.

13. Choi HJ, Park YR, Nepal M, Choi BY, Cho NP, Choi SH, et al. Inhibition of osteoclastogenic differentiation by Ikarisoside $\mathrm{A}$ in RAW 264.7 cells via JNK and NF-kappa B signaling pathways. Eur J Pharmacol 2010;636:28-35.

14. Fujisaki K, Tanabe N, Suzuki N, Kawato T, Takeichi O, Tsuzukibashi 0 , et al. Receptor activator of NF-kappa B ligand induces the expression of carbonic anhydrase II, cathepsin $\mathrm{K}$, and matrix metalloproteinase-9 in osteoclast precursor RAW264.7 cells. Life Sci 2007;80:1311-8.

15. Daniell HW, Dunn SR, Ferguson DW, Lomas G, Niazi Z, Stratte PT. Progressive osteoporosis during androgen deprivation therapy for prostate cancer. Br J Urol 2000;163:181-6.

16. Snyder PJ, Peachey H, Berlin JA, Hannoush P, Haddad G, Dlewati $A$, et al. Effects of testosterone replacement in hypogonadal men. J Clin Endocrinol Metab 2000;85:2670-7.

17. Chen Q, Kaji H, Sugimoto T, Chihara K. Testosterone inhibits osteoclast formation stimulated by parathyroid hormone through androgen receptor. FEBS Lett 2001;491:91-3.

18. Hofbauer LC, Khosla S, Dunstan CR, Lacey DL, Boyle WJ, Riggs BL. The roles of osteoprotegerin and osteoprotegerin ligand in the paracrine regulation of bone resorption. J Bone Miner Res 2000;15:2-12.

19. Vanderschueren D, Vandenput L, Boonen S, Van Herck E, Swinnen JV, Bouillon R. An aged rat model of partial androgen deficiency: prevention of both loss of bone and lean body mass by low-dose androgen replacement. Endocrinology 2000;141:1642-7.

20. Erben RG, Eberle J, Stahr K, Goldberg M. Androgen deficiency induces high turnover osteopenia in aged male rats: a sequential histomorphometric study. J Bone Miner Res 2000;15:1085-98.

21. Mohamad NV, Soelaiman IN, Chin KY. A concise review of testosterone and bone health. Clin Interventions Aging 2016;11:1317-24.

22. Murphy S, Khaw KT, Cassidy A, Compston JE. Sex hormones and bone mineral density in elderly men. Bone Miner 1993;20:133-40.

23. Scopacasa F, Horowitz M, Wishart JM, Morris HA, Chatterton BE, Need AG. The relation between bone density, free androgen index, and estradiol in men 60 to 70 y old. Bone 2000;27:145-9.
24. Takayanagi $H$, Kim $S$, Koga $T$, Nishina $H$, Isshiki M, Yoshida $H$, et al. Induction and activation of the transcription factor NFATc1 (NFAT2) integrate RANKL signaling in terminal differentiation of osteoclasts. Dev Cell 2002;3:889-901.

25. Ishida N, Hayashi K, Hoshijima M, Ogawa T, Koga S, Miyatake $\mathrm{Y}$, et al. Large-scale gene expression analysis of osteoclastogenesis in vitro and elucidation of NFAT2 as a key regulator. J Biol Chem 2002;277:41147-56.

26. Boyle WJ, Simonet WS, Lacey DL. Osteoclast differentiation and activation. Nature 2003;423:337-42.

27. Favus MJ. Bisphosphonates for osteoporosis. N Engl J Med 2010;363:2027-35.

28. Hsu H, Lacey DL, Dunstan CR, Solovyev I, Colombero A, Timms E, et al. Tumor necrosis factor receptor family member RANK mediates osteoclast differentiation and activation induced by osteoprotegerin ligand. Proc Natl Acad Sci U S A 1999;96:3540-5.

29. Delaissé JM, Engsig MT, Everts V, del Carmen Ovejero M, Ferreras $\mathrm{M}$, Lund L, et al. Proteinases in bone resorption: obvious and less obvious roles. Clin Chim Acta 2000;291:223-34.

30. Tezuka K, Nemoto K, Tezuka Y, Sato T, Ikeda Y, Kobori M, et al. Identification of matrix metalloproteinase 9 in rabbit osteoclasts. J Biol Chem 1994;269:15006-9.

31. Andersen TL, del Carmen Ovejero M, Kirkegaard T, Lenhard T, Foged NT, Delaissé JM. A scrutiny of matrix metalloproteinases in osteoclasts: evidence for heterogeneity and for the presence of MMPs synthesized by other cells. Bone 2004;35:1107-19.

32. Wilson SR, Peters C, Saftig P, Bromme D. Cathepsin K activitydependent regulation of osteoclast actin ring formation and bone resorption. J Biol Chem 2009;284:2584-92.

33. Zhao Q, Wang X, Liu Y, He A, Jia R. NFATc1: functions in osteoclasts. Int J Biochem Cell Biol 2010;42:576-9.

34. Kim K, Lee SH, Ha Kim J, Choi Y, Kim N. NFATc1 induces osteoclast fusion via up-regulation of Atp6v0d2 and the dendritic cell-specific transmembrane protein (DC-STAMP). Mol Endocrinol 2008;22:176-85.

35. Winslow MM, Pan M, Starbuck M, Gallo EM, Deng L, Karsenty G, et al. Calcineurin/NFAT signaling in osteoblasts regulates bone mass. Dev Cell 2006;10:771-82.

36. Sasaki H, Yamamoto H, Tominaga K, Masuda K, Kawai T, Teshima-Kondo S, et al. NADPH oxidase-derived reactive oxygen species are essential for differentiation of a mouse macrophage cell line (RAW264.7) into osteoclasts. J Med Invest 2009;56:33-41.

37. Yang S, Zhang Y, Ries W, Key L. Expression of Nox4 in osteoclasts. J Cell Biochem 2004;92:238-48.

38. Tang XL, Liu XI, Tian Q, Zhang W. Dynamic oxidative stress and DNA damage induced by oestrogen deficiency and protective effects of puerarin and $17 \beta$-oestradiol in ovariectomized rats. Basic Clin Pharmacol Toxicol 2012;111:87-91.

\section{How to cite this article}

- Hnin EI Thu, Zahid Hussain, Isa Naina Mohamed, Ahmad Nazrun Shuid. Dihydrotestosterone downregulates bone resorption activity of osteoclasts in dose dependent manner: an in vitro model using raw 264.7 cells. Int J Pharm Pharm Sci 2017;9(10):86-92. 